Amid all the debate following the events of September 11, 2001 and the subsequent campaign in Afghanistan, differences of opinion emerged among scholars, commentators, and officials across the Euro-Atlantic Partnership Community. This is neither surprising nor undesirable. However, much of the debate has lacked a scholarly U.S. view of the conceptual essentials underpinning American actions. The CONNECTIONS Quarterly Journal is grateful to the undersigned authors and the Institute for American Values for permission to reproduce the article below.

\title{
What We're Fighting For: A Letter from America
}

At times it becomes necessary for a nation to defend itself through force of arms. Because war is a grave matter, involving the sacrifice and taking of precious human life, conscience demands that those who would wage the war state clearly the moral reasoning behind their actions, in order to make plain to one another, and to the world community, the principles they are defending.

We affirm five fundamental truths that pertain to all people without distinction:

1. All human beings are born free ${ }^{1}$ and equal in dignity and rights.

2. The basic subject of society ${ }^{2}$ is the human person, and the legitimate role of government is to protect and help to foster the conditions for human flourishing.

3. Human beings naturally desire to seek the truth $h^{3}$ about life's purpose and ultimate ends.

4. Freedom of conscience and religious freedom ${ }^{4}$ are inviolable rights of the human person.

5. Killing in the name of God ${ }^{5}$ is contrary to faith in God and is the greatest betrayal of the universality of religious faith.

We fight to defend ourselves and to defend these universal principles.

\footnotetext{
${ }^{1}$ From the United Nations Universal Declaration of Human Rights, Article 1.

${ }^{2}$ A Call to Civil Society (New York: Institute for American Values, 1998), 16; Aristotle, Politics VII, 1-2.

${ }^{3}$ Aristotle, Metaphysics, 1-1; John Paul II, Fides et Ratio, 25 (Vatican City, 1998).

${ }^{4}$ United Nations Universal Declaration of Human Rights, Articles 18-19.

${ }^{5}$ Bosphorus Declaration (Istanbul, Turkey, February 9, 1994); Berne Declaration (Wolfsberg/Zurich, Switzerland, November 26, 1992); and John Paul II, Papal Message for World Day of Peace, Articles 6-7 (Vatican City, January 1, 2002).
} 


\section{What are American Values?}

Since September 11, millions of Americans have asked themselves and one another, Why? Why are we the targets of these hateful attacks? Why do those who would kill us, want to kill us?

We recognize that at times our nation has acted with arrogance and ignorance toward other societies. At times our nation has pursued misguided and unjust policies. Too often, we as a nation have failed to live up to our ideals. We cannot urge other societies to abide by moral principles without simultaneously admitting our own society's failure at times to abide by those same principles. We are united in our conviction - and are confident that all people of good will in the world will agree-that no appeal to the merits or demerits of specific foreign policies can ever justify, or even purport to make sense of, the mass slaughter of innocent persons.

Moreover, in a democracy such as ours, in which government derives its power from the consent of the governed, policy stems at least partly from culture, from the values and priorities of the society as a whole. Though we do not claim to possess full knowledge of the motivations of our attackers and their sympathizers, what we do know suggests that their grievances extend far beyond any one policy or set of policies. After all, the killers of September 11 issued no particular demands; in this sense, at least, the killing was done for its own sake. The leader of Al Qaeda described the "blessed strikes" of September 11 as blows against America, "the head of world infidelity." Clearly, then, our attackers despise not just our government, but our overall society, our entire way of living. Fundamentally, their grievance concerns not only what our leaders do, but also who we are.

So who are we? What do we value? For many people, including many Americans and a number of signatories to this letter, some values sometimes seen in America are unattractive and harmful: consumerism as a way of life; the notion of freedom as meaning no rules; the notion of the individual as self-made and utterly sovereign, owing little to others or to society; the weakening of marriage and family life; plus an enormous entertainment and communications apparatus that relentlessly glorifies such ideas and beams them, whether they are welcome or not, into nearly every corner of the globe.

One major task facing us as Americans, one that was important even prior to September 11, is facing honestly these unattractive aspects of our society and doing all we can to change them for the better. We pledge ourselves to this effort.

At the same time, other American values-what we view as our founding ideals, and those that most define our way of life-are quite different from these aspects, and they are much more attractive, not only to Americans, but to people everywhere in the world. Let us briefly mention four of them.

\footnotetext{
6 "Excerpt: Bin Laden Tape," Washington Post, December 27, 2001.

${ }^{7}$ See A Call to Civil Society (New York: Institute for American Values, 1998).
} 
The first is the conviction that all persons possess innate human dignity as a birthright, and that consequently each person must always be treated as an end rather than used as a means. The founders of the United States, drawing upon the natural law tradition as well as upon the fundamental religious claim that all persons are created in the image of God, affirmed as "self-evident" the idea that all persons possess equal dignity. The clearest political expression of a belief in transcendent human dignity is democracy. In the United States in recent generations, among the clearest cultural expressions of this idea has been the affirmation of the equal dignity of men and women, and of all persons, regardless of race or color.

Second, and following closely from the first, is the conviction that universal moral truths (what our nation's founders called "laws of Nature and of Nature's God") exist and are accessible to all people. Some of the most eloquent expressions of our reliance upon these truths are found in our Declaration of Independence, George Washington's Farewell Address, Abraham Lincoln's Gettysburg Address and Second Inaugural Address, and Dr. Martin Luther King, Jr.'s Letter from the Birmingham Jail.

The third is the conviction that, because our individual and collective access to truth is imperfect, most disagreements about values call for civility, openness to other views, and reasonable argument in pursuit of truth.

The fourth is freedom of conscience and freedom of religion. These intrinsically connected freedoms are widely recognized, in our own country and elsewhere, as a reflection of basic human dignity and as a precondition for other individual freedoms. ${ }^{8}$

To us, what is most striking about these values is that they apply to all persons, without distinction, and cannot be used to exclude anyone from recognition and respect based on the particularities of race, language, memory, or religion. That's why anyone, in principle, can become an American. And, in fact, anyone does. People from everywhere in the world come to our country with what a statue in New York's harbor calls a yearning to breathe free and, soon enough, they are Americans. Historically, no other nation has forged its core identity-its constitution and other founding documents, as well as its basic self-understanding — so directly and explicitly on the basis of universal human values. To us, no other fact about this country is more important.

Some people assert that these values are not universal at all, but instead derive particularly from Western, largely Christian, civilization. They argue that to conceive of these values as universal is to deny the distinctiveness of other cul-

\footnotetext{
${ }^{8}$ See John Witte Jr. and M. Christian Green, "The American Constitutional Experiment in Religious Human Rights: The Perennial Search for Principles," in Religious Human Rights in Global Perspective, vol. 2, eds. Johan D. van der Vyver and John Witte, Jr. (The Hague: Martinus Nijhoff Publishers, 1996). See also Harold J. Berman, Law and Revolution: The Formation of the Western Legal Tradition (Cambridge, MA: Harvard University Press, 1983); and Michael J. Perry, The Idea of Human Rights: Four Inquiries (New York: Oxford University Press, 1998).
} 


\section{THE QUARTERLY JOURNAL}

tures. ${ }^{9}$ We disagree. We recognize our own civilization's achievements, but we believe that all people are created equal. We believe in the universal possibility and desirability of human freedom. We believe that certain basic moral truths are recognizable everywhere in the world. We agree with the international group of distinguished philosophers who in the late 1940s helped to shape the United Nations' Universal Declaration of Human Rights, and who concluded that a few fundamental moral ideas are so widespread that they "may be viewed as implicit in man's nature as a member of society." ${ }^{\prime 10}$ In hope, and on the evidence, we agree with Dr. Martin Luther King, Jr., that "the arc of the moral universe is long, but it bends toward justice,"11 not just for the few, or the lucky, but for all people.

Looking at our own society, we acknowledge again the all-too-frequent gaps between our ideals and our conduct. But as Americans in a time of war and global crisis, we are also suggesting that the best of what we too casually call "American values" do not belong only to America, but are in fact the shared inheritance of humankind, and therefore a possible basis of hope for a world community based on peace and justice.

\section{What about God?}

Since September 11, millions of Americans have asked themselves and one another, What about God? Crises of this magnitude force us to think anew about first principles. When we contemplate the horror of what has occurred, and the danger of what is likely to come, many of us ask: Is religious faith part of the solution or part of the problem?

The signatories to this letter come from diverse religious and moral traditions, including secular traditions. We are united in our belief that invoking God's authority to kill or maim human beings is immoral and is contrary to faith in God. Many of us believe that we are under God's judgment. None of us believe that God ever instructs some of us to kill or conquer others of us. Indeed, such an attitude, whether it is called a "holy war" or "crusade," not only violates basic principles of justice but is in fact a negation of religious faith, since it turns God into an idol to be used for man's own purposes. ${ }^{12}$ Our own nation was once engaged in a great civil war, in which each side presumed God's aid against the other. In his Second

\footnotetext{
${ }^{9}$ Some people make this point as a way of condemning those "other" cultures that are presumably too inferior, or too enthralled by false beliefs, to appreciate what we in this letter are calling universal human values; others make this point as a way of endorsing (usually one of) those cultures that are presumably indifferent to these values. We disagree with both versions of this point.

${ }^{10}$ Richard McKeon, "The Philosophic Bases and Material Circumstances of the Rights of Man," in Human Rights: Comments and Interpretations (London: Wingate, 1949), 45.

${ }^{11}$ Martin Luther King, Jr., "Where Do We Go From Here?", in The Essential Writings and Speeches of Martin Luther King, Jr., ed. James M. Washington (New York: HarperCollins, 1986), 245.

12 John Paul II, Papal Message for World Day of Peace, Article 6 (Vatican City, January 1, 2002).
} 
Inaugural Address in 1865, the sixteenth president of the United States, Abraham Lincoln, put it simply: "The Almighty has his own purposes."

Those who attacked us on September 11 openly proclaim that they are engaged in a holy war. Many who support or sympathize with the attackers also invoke God's name, and seem to embrace the rationale of holy war. But to recognize the disaster of this way of thinking, we as Americans need only to remember our own, and Western, history. Christian religious wars and Christian sectarian violence tore apart Europe for the better part of a century. In the United States, we are no strangers to those who would murder at least in part in the name of their religious faith. When it comes to this particular evil, no civilization and no religious tradition is spotless. ${ }^{13}$

The human person has a basic drive to question in order to know. Evaluating, choosing, and having reasons for what we value and love are characteristically human activities. ${ }^{14}$ Part of this intrinsic desire to know concerns why we are born and what will happen when we die, which leads us to seek the truth about ultimate ends, including, for many people, the question of God. Some of the signatories to this letter believe that human beings are by nature "religious," in the sense that everyone, including those who do not believe in God and do not participate in organized religion, makes choices about what is important and reflects on ultimate values. All of the signatories to this letter recognize that, across the world, religious faith and religious institutions are important bases of civil society, often producing results for society that are beneficial and healing, at times producing results that are divisive and violent.

So how can governments and societal leaders best respond to these fundamental human and social realities? One response is to outlaw or repress religion. An-

\footnotetext{
${ }^{13}$ Intra-Christian examples of holy war or crusades emerged with particular force in Europe during the 17 th century. According to some scholars, the principal characteristics of holy war are: that the cause for which the war is fought has a clear connection to religion (i.e., that the cause is "holy"); that the war is fought under the banner and with the presumption of divine authority and assistance (the Latin term used by $11^{\text {th }}$ century Christian crusaders was "Deus Volt," or "God wills it"); that the warriors understand themselves to be godly, or "warrior saints"; that the war is prosecuted zealously and unsparingly, since the enemy is presumed to be ungodly and therefore fundamentally "other," lacking the human dignity and rights of the godly; and, finally, that warriors who die in battle are favored by God as martyrs. Eventually, in Christianity, the development of just war doctrine, with its emphasis on moral universalism, largely called for the elimination of religion as a just cause for war. As early as the 16th century, some natural law theorists such as Franciscus de Victoria and Francisco Suarez were explicitly condemning the use of war to spread religion. "Difference in religion," Victoria wrote, "is not a cause of just war." See James Turner Johnson, Ideology, Reason, and the Limitation of War: Religious and Secular Concepts 1200 - 1740 (Princeton: Princeton University Press, 1975), 112-123, 154. See also Roland H. Bainton, Christian Attitudes Toward War and Peace: A Historical Survey and Critical Re-evaluation (Nashville: Abingdon, 1960), 148.

${ }^{14}$ A Call to Civil Society (New York: Institute for American Values, 1998), 16. This theme is developed in Aristotle, Metaphysics, 1-1; Bernard J. Lonergan, Insight: A Study of Human Understanding (New York: Longmans, 1958); and others.
} 


\section{THE QUARTERLY JOURNAL}

other possible response is to embrace an ideological secularism ${ }^{15}$ - a strong societal skepticism or hostility regarding religion, based on the premise that religion itself, and especially any public expression of religious conviction, is inherently problematic. A third possible response is to embrace theocracy-the belief that one religion, presumably the one true religion, should be effectively mandatory for all members of society and therefore should receive complete or significant state sponsorship and support.

We disagree with each of these responses. Legal repression radically violates civil and religious freedom and is incompatible with democratic civil society. Although ideological secularism may have increased in our society in recent generations, we disagree with it because it would deny the public legitimacy of an important part of civil society, as well as seek to suppress or deny the existence of what is at least arguably an important dimension of personhood itself. ${ }^{16}$ Although theocracy has been present in western (though not U.S.) history, we disagree with it for both social and theological reasons. Socially, governmental establishment of a particular religion can conflict with the principle of religious freedom, a fundamental human right. In addition, government control of religion can cause or exacerbate religious conflicts and, perhaps even more importantly, can threaten the vitality and authenticity of religious institutions. Theologically, even for those who are firmly convinced of the truth of their faith, the coercion of others in matters of religious conscience is ultimately a violation of religion itself, since it robs those other persons of the right to respond freely and with dignity to the Creator's invitation. At its best, the United States seeks to be a society in which faith and freedom can go together, each elevating the other. We have a secular state-our government officials are not simultaneously religious officials-but we are by far the Western world's most religious society. We are a nation that deeply respects religious freedom and diversity, including the rights of nonbelievers, but one whose citizens recite a Pledge of Allegiance to "one nation, under God," and one that proclaims in many of its courtrooms and inscribes on each of its coins the motto, "In God We Trust." Politically, our separation of church and state seeks to keep politics within its proper sphere, in part by limiting the state's power to control

\footnotetext{
${ }^{15}$ We wish here to distinguish "secular" from "secularism." Secular, derived from the Latin term meaning "world," and suggesting "in the world," refers merely to functions that are separate from the church. Secularism, by contrast, is a philosophy, an "ism," a way of seeing the world based on rejection of religion or hostility to religion.

${ }^{16}$ For this reason, advocates of secularism may underestimate the degree to which human societies, even in theory, can simply dispense with "religion." Moreover, they almost certainly miscalculate, even accepting many of their own premises, the social consequences of suppressing traditional religion. For if we understand religion to be values of ultimate concern, the 20th century saw two world-threatening examples-Nazism in Germany and communism in the Soviet Union-of the emergence of secular religions, or what might be called replacement religions, each violently intent on eliminating its society's traditional religious faiths (in effect, its competitor faiths) and each, when in power, ruthlessly indifferent to human dignity and basic human rights.
} 
religion, and in part by causing government itself to draw legitimacy from, and operate under, a larger moral canopy that is not of its own making. ${ }^{17}$ Spiritually, our separation of church and state permits religion to be religion, by detaching it from the coercive power of government. In short, we seek to separate church and state for the protection and proper vitality of both. ${ }^{18}$

For Americans of any religious faith, the challenge of embracing religious truth and religious freedom has often been difficult. The matter, moreover, is never settled. Ours is a social and constitutional arrangement that almost by definition requires constant deliberation, debate, adjustment, and compromise. It is also helped by, and helps to produce, a certain character or temperament, such that religious believers who strongly embrace the truth of their faith also-not as a compromise with that truth but as an aspect of it—respect those who take a different path.

What will help to reduce religiously-based mistrust, hatred, and violence in the 21 st century? There are many important answers to this question, of course, but here, we hope, is one: Deepening and renewing our appreciation of religion by recognizing religious freedom as a fundamental right of all people in every nation.

\section{A Just War?}

We recognize that all war is terrible, representative finally of human political failure. We also know that the line separating good and evil does not run between one society and another, much less between one religion and another; ultimately, that line runs through the middle of every human heart. ${ }^{19}$ Finally, those of us-Jews, Christians, Muslims, and others-who are people of faith recognize our responsibility, stated in our holy scriptures, to love mercy and to do all in our power to prevent war and live in peace.

Yet reason and careful moral reflection also teach us that there are times when the first and most important reply to evil is to stop it. There are times when waging war is not only morally permitted, but morally necessary, as a response to calamitous acts of violence, hatred, and injustice. This is one of those times.

\footnotetext{
${ }^{17}$ As the leaders and scholars who produced The Williamsburg Charter put it in 1988, "the government acts as a safeguard, but not the source, of freedom for faiths, whereas the churches and synagogues act as a source, but not the safeguard, of faiths for freedom ....The result is neither a naked public square where all religion is excluded, nor a sacred public square with any religion established or semi-established. The result, rather, is a civil public square in which citizens of all religious faiths, or none, engage one another in the continuing democratic discourse." See James Davison Hunter and Os Guinness, eds., Articles of Faith, Articles of Peace: The Religious Liberty Clauses and the American Public Philosophy (Washington, D.C.: The Brookings Institution, 1990), 140.

${ }^{18}$ A Call to Civil Society (New York: Institute for American Values, 1998), 13.

${ }^{19}$ See Alexander Solzhenitzyn, The Gulag Archipelago, Vol. I (New York: Harper and Row, 1974), 168.
} 


\section{THE QUARTERLY JOURNAL}

The idea of a "just war" is broadly based, with roots in many of the world's diverse religious and secular moral traditions. ${ }^{20}$ Jewish, Christian, and Muslim teachings, for example, all contain serious reflections on the definition of a just war. To be sure, some people, often in the name of realism, insist that war is essentially a realm of self-interest and necessity, making most attempts at moral analysis irrelevant. ${ }^{21}$ We disagree. ${ }^{22}$ Moral inarticulateness in the face of war is itself a moral stance, one that rejects the possibility of reason, accepts normless-

\footnotetext{
${ }^{20}$ See Jean Bethke Elshtain, ed., Just War Theory (Oxford: Blackwell, 1992); Elshtain, Stanley Hauerwas, and James Turner Johnson, Pew Forum on Religion and Public Life Conference on "Just War Tradition and the New War on Terrorism" (http://pewforum.org/events/1005/); James Turner Johnson, Ideology, Reason, and the Limitation of War: Religious and Secular Concepts 1200 - 1740 (Princeton: Princeton University Press, 1975); James Turner Johnson, Just War Tradition and the Restraint of War: A Moral and Historical Inquiry (Princeton: Princeton University Press, 1981); Johnson, The Quest for Peace: Three Moral Traditions in Western Cultural History (Princeton: Princeton University Press, 1987); Johnson, Morality and Contemporary Warfare (New Haven: Yale University Press, 1999); Johnson and John Kelsay, eds., Cross, Crescent, and Sword: The Justification and Limitation of War in Western and Islamic Tradition (New York: Greenwood Press, 1990); Majid Khadduri, War and Peace in the Law of Islam (Baltimore: Johns Hopkins University Press, 1955); John Kelsay and James Turner Johnson, eds., Just War and Jihad: Historical and Theoretical Perspectives on War and Peace in Western and Islamic Tradition (New York: Greenwood Press, 1991); Terry Nardin, ed., The Ethics of War and Peace: Religious and Secular Perspectives (Princeton: Princeton University Press, 1996); William V. O'Brien, The Conduct of War and Limited War (New York: Praeger, 1981); Rudolf Peters, Jihad in Classical and Modern Islam (Princeton: Markus Wiener, 1996); Paul Ramsey, Speak Up for Just War or Pacifism (University Park, PA: Pennsylvania State University Press, 1988); Michael Walzer, Just and Unjust Wars (New York: Basic Books, 1977); and Richard Wasserstrom, ed., War and Morality (Belmont, CA: Wadsworth, 1970).

${ }^{21}$ The Latin axiom is: Inter arma silent leges (In times of war the law is silent). Classical exemplars of this perspective include Thucydides, Niccolo Machiavelli and Thomas Hobbes; for a more recent treatment, see Kenneth Waltz, Man, the State and War (Princeton: Princeton University Press, 1978). For a sensitive but critical survey of the contribution of this school of thought to international theory, see Jack Donnelly, Realism and International Relations (Cambridge: Cambridge University Press, 2000).

${ }^{22}$ Intellectual and moral approaches to war as a human phenomenon can generally be divided into four schools of thought. The first can be called realism: the belief that war is basically a matter of power, self-interest, necessity, and survival, thereby rendering abstract moral analysis largely beside the point. The second can be called holy war: the belief that God can authorize the coercion and killing of nonbelievers, or that a particular secular ideology of ultimate concern can authorize the coercion and killing of nonbelievers. The third can be called pacifism: the belief that all war is intrinsically immoral. And the fourth is typically called just war: the belief that universal moral reasoning, or what some would call natural moral law, can and should be applied to the activity of war. The signatories to this letter largely disagree with the first school of thought. We unequivocally reject the second school of thought, regardless of the form it takes, or whether it springs from and purports to support our own society ("our side") or the side of those who wish us ill. Some of the signatories have much respect for the third school of thought (particularly its insistence that non-violence does not mean retreat or passivity or declining to stand for justice, but often means quite the opposite), even as we respectfully, and with some degree of fear and trembling, differ from it. As a group we seek largely to embrace and build upon the fourth school of thought.
} 
ness in international affairs, and capitulates to cynicism. To seek to apply objective moral reasoning to war is to defend the possibilities of a civil society and a world community based on justice.

The principles of just war teach us that wars of aggression and aggrandizement are never acceptable. Wars may not legitimately be fought for national glory, to avenge past wrongs, for territorial gain, or for any other non-defensive purpose.

The primary moral justification for war is to protect the innocent from certain harm. Augustine, whose early fifth-century book, The City of God, is a seminal contribution to just war thinking, argued (echoing Socrates ${ }^{23}$ ) that it is better for the Christian as an individual to suffer harm rather than to commit it. But is the morally responsible person also required, or even permitted, to make for other innocent persons a commitment to non-self-defense? For Augustine, and for the broader just war tradition, the answer is no. If one has compelling evidence that innocent people who are in no position to protect themselves will be grievously harmed unless coercive force is used to stop an aggressor, then the moral principle of love of our neighbor calls us to the use of force.

Wars may not legitimately be fought against dangers that are small, questionable, or of uncertain consequence, or against dangers that might plausibly be mitigated solely through negotiation, appeals to reason, persuasion from third parties, or other non-violent means. ${ }^{24}$ But if the danger to innocent life is real and certain, and especially if the aggressor is motivated by implacable hostility-if the end he seeks is not your willingness to negotiate or comply, but rather your destructionthen a resort to proportionate force is morally justified.

A just war can only be fought by a legitimate authority with responsibility for public order. Violence that is free-lance, opportunistic, or individualistic is never morally acceptable. ${ }^{25}$

\footnotetext{
${ }^{23}$ Socrates' judgment that it is better to suffer evil rather than to do it is conveyed to us by Plato in the Apology (32-c to 32-e) and constitutes a key moment in moral philosophy.

${ }^{24}$ Some people suggest that the "last resort" requirement of just war theory-in essence, the requirement to explore all other reasonable and plausible alternatives to the use of force-is not satisfied until the resort to arms has been approved by a recognized international body, such as the United Nations. This proposition is problematic. First, it is novel; historically, approval by an international body has not been viewed by just war theorists as a just cause requirement. Second, it is quite debatable whether an international body such as the UN is in a position to be the best final judge of when, and under what conditions, a particular resort to arms is justified, or whether the attempt by that body to make and enforce such judgments would inevitably compromise its primary mission of humanitarian work. According to one observer, a former UN Assistant Secretary-General, transforming the UN into "a pale imitation of a state" in order to "manage the use of force" internationally "may well be a suicidal embrace." See Giandomenico Picco, "The U.N. and the Use of Force," Foreign Affairs 73 (1994): 15. See also Thomas G. Weis, David P. Forsythe, and Roger A. Coate, United Nations and Changing World Politics (Boulder, CO: Westview Press, 2001), 104-106; and John Gerard Ruggie, The United Nations and the Collective Use of Force: Whither? Or Whether? (New York: United Nations Association of the USA, 1996).

${ }^{25}$ In just war theory, the main goal of the legitimate authority requirement is to prevent the anarchy
} 


\section{THE QUARTERLY JOURNAL}

A just war can only be waged against persons who are combatants. Just war authorities from across history and from around the world - whether they be Muslim, Jewish, Christian, from other faith traditions, or secular-consistently teach us that noncombatants are immune from deliberate attack. Thus, killing civilians for revenge, or even as a means of deterring aggression from people who sympathize with them, is morally wrong. Although in some circumstances, and within strict limits, it can be morally justifiable to undertake military actions that may result in the unintended but foreseeable death or injury of some noncombatants, it is not morally acceptable to make the killing of noncombatants the operational objective of a military action.

These and other just war principle ${ }^{26}$ teach us that, whenever human beings contemplate or wage war, it is both possible and necessary to affirm the sanctity of human life and to embrace the principle of equal human dignity. These principles strive to preserve and reflect, even amid the tragic activity of war, the fundamental moral truth that "others"- - those who are strangers to us, those who differ from us in race or language, those whose religions we may believe to be untrue- - have the

of private warfare and warlords - an anarchy that exists today in some parts of the world, and of which the attackers of September 11 are representative embodiments. The legitimate authority requirement does not, on the other hand, for several reasons, apply clearly or directly to wars of national independence or succession. First, these latter types of conflict occur within a state, not internationally. Moreover, in many such conflicts, the question of public legitimacy is exactly what is being contested. For example, in the war for independence that resulted in the founding of the United States, just war analysts frequently point out that the rebelling colonies themselves constituted a legitimate public authority, and, further, that the colonies had reasonably concluded that the British government had, in the words of our Declaration of Independence, become "destructive of these ends" of legitimate government, and therefore itself had ceased to function as a competent public authority. Indeed, even in cases in which those waging war do not in any plain sense constitute a currently functioning public authority - for example, the Warsaw Ghetto Uprising of Polish Jews in 1943 against the Nazi occupation - the legitimate authority requirement of just war theory does not morally invalidate the resort to arms by those seeking to overthrow illegitimate authority.

${ }^{26}$ For example, just war principles often insist that legitimate warfare must be motivated by the intention of enhancing the likelihood of peace and reducing the likelihood of violence and destruction; that it must be proportionate, such that the social goods that would result from victory in war discernibly outweigh the evils that will attend the war; that it must contain the probability of success, such that lives are not taken and sacrificed in futile causes; and that it must pass the test of comparative justice, such that the human goods being defended are important enough, and gravely enough in danger, to outweigh what many just war theorists view as the standing moral presumption against war. This letter focuses largely on principles of justice in declaring war (in the terminology employed by many Christian just war thinkers, jus ad bellum) and in waging war (jus in bello). Other principles focus on justice in settling the war and restoring conditions of peace (jus post bellum). See Jean Bethke Elshtain, ed., Just War Theory (Oxford: Blackwell, 1992); U.S. Conference of Catholic Bishops, The Challenge of Peace: God's Promise and Our Response (Washington, D.C.: United States Catholic Conference, 1983); and other sources cited above in note 20. 
same right to life that we do, and the same human dignity and human rights that we do.

On September 11, 2001, a group of individuals deliberately attacked the United States, using hijacked airplanes as weapons with which to kill in less than two hours over 3,000 of our citizens ${ }^{27}$ in New York City, southwestern Pennsylvania, and Washington, D.C. Overwhelmingly, those who died on September 11 were civilians, not combatants, and were not known at all, except as Americans, to those who killed them. Those who died on the morning of September 11 were killed unlawfully, wantonly, and with premeditated malice - a kind of killing that, in the name of precision, can only be described as murder. Those murdered include people from all races, many ethnicities, most major religions. They included dishwashers and corporate executives.

The individuals who committed these acts of war did not act alone, or without support, or for unknown reasons. They were members of an international Islamicist network, active in as many as 40 countries, now known to the world as $\mathrm{Al}$ Qaeda. This group, in turn, constitutes but one arm of a larger radical Islamicist movement - growing for decades and, in some instances, tolerated and even supported by governments - that openly professes its desire and increasingly demonstrates its ability to use murder to advance its objectives. ${ }^{28}$

We use the terms "Islam" and "Islamic" to refer to one of the world's great religions, one with about 1.2 billion adherents, including several million U.S. citizens, some of whom were murdered on September 11. It ought to go without saying — but we say it here once, clearly — that the great majority of the world's Muslims, guided in large measure by the teachings of the Qur'an, are decent, faith-

\footnotetext{
${ }^{27}$ As of January 4, 2002, official estimates were that 3,119 persons had been killed by the September 11 attackers, including 2,895 in New York, 184 in Washington, and 40 in Pennsylvania. Although this letter refers to "our citizens," included among those murdered on September 11 were many citizens of other countries who were living in the U.S. at the time of the attack. "Dead and Missing," New York Times, January 8, 2002.

${ }^{28}$ In addition to the murders of September 11, members of radical Islamicist organizations are apparently responsible for: the April 18, 1983 bombing of the U.S. Embassy in Beirut, killing 63 persons and injuring 120; the October 23, 1983 bombings of U.S. Marine and French paratroop barracks in Beirut, killing 300 persons; the December 21, 1988 bombing of Pan Am Flight 103, killing 259 persons; the February 26, 1993 bombing of the World Trade Center in New York City, killing six persons and injuring 1000; the June 25, 1996 bombing outside the Khobar Towers U.S. military barracks in Dhahran, Saudi Arabia, killing 19 U.S. soldiers and wounding 515; the August 7, 1998 bombing of U.S. embassies in Nairobi, Kenya, and Dar es Salaam, Tanzania, killing 224 persons and injuring more than 5,000; and the October 12, 2000 bombing of the USS Cole in Aden, Yemen, killing 17 U.S. sailors and wounding 39. This list is incomplete. (See Significant Terrorist Incidents, 1961-2001 (Washington, D.C.: U.S. Department of State, Bureau of Public Affairs, October 31, 2001). In addition, members of organizations comprising this movement are also responsible for numerous failed attempts at mass murder, both in the U.S. and in other countries, including the attempt to bomb the United Nations and the Lincoln and Holland Tunnels in New York in 1993 and the attempt to bomb the Los Angeles International Airport on New Year's Eve, 2000.
} 


\section{THE QUARTERLY JOURNAL}

ful, and peaceful. We use the terms "Islamicism" and "radical Islamicist" to refer to the violent, extremist, and radically intolerant religious-political movement that now threatens the world, including the Muslim world.

This radical, violent movement opposes not only certain U.S. and Western policies (some signatories to this letter also oppose some of those policies), but also a foundational principle of the modern world, religious tolerance, as well as those fundamental human rights, in particular freedom of conscience and religion, that are enshrined in the United Nations' Universal Declaration of Human Rights and that must be the basis of any civilization oriented to human development, justice, and peace.

This extremist movement claims to speak for Islam, but betrays fundamental Islamic principles. Islam sets its face against moral atrocities. For example, reflecting the teaching of the Qur'an and the example of the Prophet, Muslim scholars through the centuries have taught that struggle in the path of God (i.e., jiha $\not^{9}$ ) forbids the deliberate killing of noncombatants and requires that military action be undertaken only at the behest of legitimate public authorities. They remind us forcefully $^{30}$ that Islam, no less than Christianity, Judaism, and other religions, is threatened and potentially degraded by these profaners who invoke God's name to kill indiscriminately.

We recognize that movements claiming the mantle of religion also have complex political, social, and demographic dimensions, to which due attention must be

\footnotetext{
${ }^{29}$ The relationship between the jihad and just war traditions is complex. Pre-modern jihad and just war perspectives overlapped in important ways. Both could legitimate wars aimed at advancing religion, and both sought clearly to disassociate such wars from wars involving indiscriminate or disproportionate tactics. In the modern era, jihad has largely retained its confessional component - that is, its aim of protecting and propagating Islam as a religion. The confessional dimension of jihad thinking in turn seems to be closely linked to the view of the state widely held by Muslim authorities, a view that envisions little or no separation of religion from the state. By contrast, modern Christian thinking on just war has tended to downplay its confessional elements (few Christian theologians today emphasize the value of "crusades"), replacing them with more religiously neutral arguments about human rights and shared moral norms, or what some Christian and other thinkers term "natural moral law." Some Muslim scholars today seek, in the case of jihad, to more fully recover the sense of the term as "exertion" or "striving for good" in the service of God, thereby similarly downplaying its confessional elements and emphasizing, for our increasingly plural and interdependent world, the term's more universal dimensions and applications. For example, see Sohail M. Hashmi, "Interpreting the Islamic Ethics of War and Peace," in The Ethics of War and Peace: Religious and Secular Perspectives, ed. Terry Nardin (Princeton: Princeton University Press, 1996), 146-166; and Hilmi Zawati, Is Jihad a Just War? War, Peace, and Human Rights under Islamic and Public International Law (Lewiston, NY: Edwin Mellen, 2001).

${ }^{30}$ For example, Muslim scholars affiliated with the Muslim World League recently reaffirmed at a meeting in Mecca that jihad strictly prohibits "the killing of noncombatants" and attacks against "installations, sites and buildings not related to the fighting." See "Muslim scholars define "terrorism' as opposed to legitimate jihad," Middle East News Online [www.middleeastwire.com], posted January 14, 2002. See also Bassam Tibi, "War and Peace in Islam," in Nardin, ed., 128145.
} 
paid. At the same time, philosophy matters, and the animating philosophy of this radical Islamicist movement - in its contempt for human life, and by viewing the world as a life-or-death struggle between believers and unbelievers (whether nonradical Muslims, Jews, Christians, Hindus, or others) — clearly denies the equal dignity of all persons, and in doing so betrays religion and rejects the very foundation of civilized life and the possibility of peace among nations.

Most seriously of all, the mass murders of September 11 demonstrated, arguably for the first time, that this movement now possesses not only the openlystated desire, but also the capacity and expertise-including possible access to, and willingness to use, chemical, biological, and nuclear weapons- to wreak massive, horrific devastation on its intended targets. ${ }^{31}$

Those who slaughtered more than 3,000 persons on September 11 and who, by their own admission, want nothing more than to do it again, constitute a clear and present danger to all people of good will everywhere in the world, not just in the United States. Such acts are a pure example of naked aggression against innocent human life, a world-threatening evil that clearly requires the use of force to remove it.

Organized killers with global reach now threaten all of us. In the name of universal human morality, and fully conscious of the restrictions and requirements of a just war, we support our government's, and our society's, decision to use force of arms against them.

\section{Conclusion}

We pledge to do all we can to guard against the harmful temptations-especially those of arrogance and jingoism-to which nations at war so often seem to yield. At the same time, with one voice we solemnly say that it is crucial for our nation and its allies to win this war. We fight to defend ourselves, but we also believe that we fight to defend those universal principles of human rights and human dignity that are the best hope for humankind.

One day, this war will end. When it does-and, in some respects, even before it ends - the great task of conciliation awaits us. We hope that this war, by stopping an unmitigated global evil, can increase the possibility of a world community based on justice. But we know that only the peacemakers among us, in every society, can ensure that this war will not have been in vain.

\footnotetext{
${ }^{31}$ The historian Eric Hobsbawm, in his study of the 20th century, published in 1995, particularly warns us, as we confront the new millennium, of the emerging crisis of "non-state terrorism" made possible by the growing "privatization of the means of destruction," such that organized groups, operating at least to some degree independently of public authorities, are increasingly willing and able to perpetrate "violence and wreckage anywhere on the globe." Eric Hobsbawm, Age of Extremes: The Short Twentieth Century 1914-1991 (London: Abacus, 1995), 560.
} 


\section{THE QUARTERLY JOURNAL}

We wish especially to reach out to our brothers and sisters in Muslim societies. We say to you forthrightly: We are not enemies, but friends. ${ }^{32}$ We must not be enemies. We have so much in common. There is so much that we must do together. Your human dignity, no less than ours-your rights and opportunities for a good life, no less than ours-are what we believe we are fighting for. We know that, for some of you, mistrust of us is high, and we know that we Americans are partly responsible for that mistrust. But we must not be enemies. In hope, we wish to join with you and all people of good will to build a just and lasting peace.

\section{Signatories}

Enola Aird Director, The Motherhood Project; Council on Civil Society

John Atlas President, National Housing Institute; Executive Director, Passaic County Legal Aid Society

Jay Belsky Professor and Director, Institute for the Study of Children, Families and Social Issues, Birkbeck University of London

David Blankenhorn President, Institute for American Values

David Bosworth University of Washington

R. Maurice Boyd Minister, The City Church, New York

Gerard V. Bradley Professor of Law, University of Notre Dame

Margaret F. Brinig Edward A. Howry Distinguished Professor, University of Iowa College of Law

Allan Carlson President, The Howard Center for Family, Religion, and Society

Khalid Durán Editor, TransIslam Magazine

Paul Ekman Professor of Psychology, University of California, San Francisco

Jean Bethke Elshtain Laura Spelman Rockefeller Professor of Social and Political Ethics, University of Chicago Divinity School

Amitai Etzioni University Professor, The George Washington University

Hillel Fradkin President, Ethics and Public Policy Center

Samuel G. Freedman Professor, Columbia University Graduate School of Journalism

Francis Fukuyama Bernard Schwartz Professor of International Political Economy, Johns Hopkins University

William A. Galston Professor, School of Public Affairs, University of Maryland; Director, Institute for Philosophy and Public Policy

Claire Gaudiani Senior research scholar, Yale Law School, and former president, Connecticut College

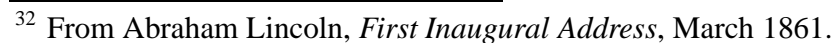


Robert P. George McCormick Professor of Jurisprudence and Professor of Politics, Princeton University

Neil Gilbert Professor, School of Social Welfare, University of California, Berkeley

Mary Ann Glendon Learned Hand Professor of Law, Harvard University Law School

Norval D. Glenn Ashbel Smith Professor of Sociology and Stiles Professor of American Studies, University of Texas at Austin

Os Guinness Senior Fellow, Trinity Forum

David Gutmann Professor Emeritus of Psychiatry and Education, Northwestern University

Kevin J. "Seamus" Hasson President, Becket Fund for Religious Liberty

Sylvia Ann Hewlett Chair, National Parenting Association

James Davison Hunter William R. Kenan, Jr., Professor of Sociology and Religious Studies and Executive Director, Center on Religion and Democracy, University of Virginia

Samuel Huntington Albert J. Weatherhead, III, University Professor, Harvard University

Byron Johnson Director and Distinguished Senior Fellow, Center for Research on Religion and Urban Civil Society, University of Pennsylvania

James Turner Johnson Professor, Department of Religion, Rutgers University

John Kelsay Richard L. Rubenstein Professor of Religion, Florida State University

Diane Knippers President, Institute on Religion and Democracy

Thomas C. Kohler Professor of Law, Boston College Law School

Glenn C. Loury Professor of Economics and Director, Institute on Race and Social Division, Boston University

Harvey C. Mansfield William R. Kenan, Jr., Professor of Government, Harvard University

Will Marshall President, Progressive Policy Institute

Richard J. Mouw President, Fuller Theological Seminary

Daniel Patrick Moynihan University Professor, Maxwell School of Citizenship and Public Affairs, Syracuse University

John E. Murray, Jr. Chancellor and Professor of Law, Duquesne University

Michael Novak George Frederick Jewett Chair in Religion and Public Policy, American Enterprise Institute

Rev. Val J. Peter Executive Director, Boys and Girls Town

David Popenoe Professor of Sociology and Co-Director, National Marriage Project, Rutgers University 
THE QUARTERLY JOURNAL

Robert D. Putnam Peter and Isabel Malkin Professor of Public Policy, Kennedy School of Government, Harvard University

Gloria G. Rodriguez Founder and President, AVANCE, Inc.

Robert Royal President, Faith \& Reason Institute

Nina Shea Director, Freedom's House's Center for Religious Freedom

Fred Siegel Professor of History, The Cooper Union

Theda Skocpol Victor S. Thomas Professor of Government and Sociology, Harvard University

Katherine Shaw Spaht Jules and Frances Landry Professor of Law, Louisiana State University Law Center

Max L. Stackhouse Professor of Christian Ethics and Director, Project on Public Theology, Princeton Theological Seminary

William Tell, Jr. The William and Karen Tell Foundation

Maris A. Vinovskis Bentley Professor of History and Professor of Public Policy, University of Michigan

Paul C. Vitz Professor of Psychology, New York University

Michael Walzer Professor, School of Social Science, Institute for Advanced Study

George Weigel Senior Fellow, Ethics and Public Policy Center

Charles Wilson Director, Center for the Study of Southern Culture, University of Mississippi

James Q. Wilson Collins Professor of Management and Public Policy Emeritus, UCLA

John Witte, Jr. Jonas Robitscher Professor of Law and Ethics and Director, Law and Religion Program, Emory University Law School

Christopher Wolfe Professor of Political Science, Marquette University

Daniel Yankelovich President, Public Agenda

The signatories wish to thank Dan Cere of McGill University in Montreal for research and editorial assistance. 